This article was downloaded by: [North Carolina State University]

On: 05 May 2014, At: 05:24

Publisher: Taylor \& Francis

Informa Ltd Registered in England and Wales Registered Number: 1072954 Registered office: Mortimer House, 37-41 Mortimer Street, London W1T 3J H, UK

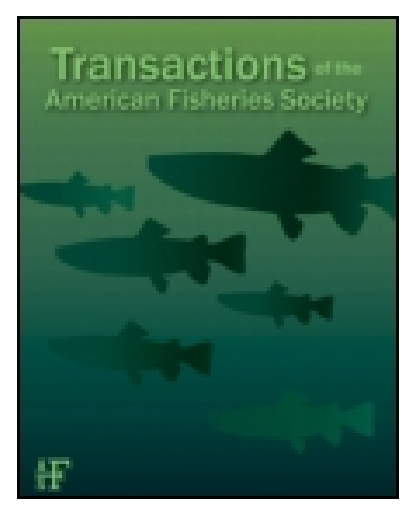

\title{
Transactions of the American Fisheries Society
}

Publication details, including instructions for authors and subscription information:

http:// www.tandfonline.com/loi/ utaf20

\section{American Shad Migratory Behavior, Weight Loss, Survival, and Abundance in a North Carolina River following Dam Removals}

\author{
J oshua K. Raabe ${ }^{\text {ac }} \&$ J oseph E. Hightower ${ }^{b}$ \\ ${ }^{a}$ North Carolina Cooperative Fisheries and Wildlife Research Unit, Department of Applied \\ Ecology, North Carolina State University, 127 David Clark Labs, Campus Box 7617, Raleigh, \\ North Carolina 27695-7617, USA \\ ${ }^{b}$ U. S. Geological Survey, North Carolina Cooperative Fish and Wildlife Research Unit, \\ Department of Applied Ecology, North Carolina State University, 127 David Clark Labs, \\ Campus Box 7617, Raleigh, North Carolina 27695-7617, USA \\ ' Present address: College of Natural Resources; University of Wisconsin-Stevens Point, 800 \\ Reserve Street, Stevens Point, Wisconsin 54418-3897, USA \\ Published online: 29 Apr 2014.
}

To cite this article: J oshua K. Raabe \& J oseph E. Hightower (2014) American Shad Migratory Behavior, Weight Loss, Survival, and Abundance in a North Carolina River following Dam Removals, Transactions of the American Fisheries Society, 143:3, 673-688

To link to this article: http:// dx. doi. org/ 10.1080/00028487.2014.882410

\section{PLEASE SCROLL DOWN FOR ARTICLE}

Taylor \& Francis makes every effort to ensure the accuracy of all the information (the "Content") contained in the publications on our platform. However, Taylor \& Francis, our agents, and our licensors make no representations or warranties whatsoever as to the accuracy, completeness, or suitability for any purpose of the Content. Any opinions and views expressed in this publication are the opinions and views of the authors, and are not the views of or endorsed by Taylor \& Francis. The accuracy of the Content should not be relied upon and should be independently verified with primary sources of information. Taylor and Francis shall not be liable for any losses, actions, claims, proceedings, demands, costs, expenses, damages, and other liabilities whatsoever or howsoever caused arising directly or indirectly in connection with, in relation to or arising out of the use of the Content.

This article may be used for research, teaching, and private study purposes. Any substantial or systematic reproduction, redistribution, reselling, loan, sub-licensing, systematic supply, or distribution in any form to anyone is expressly forbidden. Terms \& Conditions of access and use can be found at http:// www.tandfonline.com/page/terms-and-conditions 


\title{
American Shad Migratory Behavior, Weight Loss, Survival, and Abundance in a North Carolina River following Dam Removals
}

\author{
Joshua K. Raabe*1 \\ North Carolina Cooperative Fisheries and Wildlife Research Unit, Department of Applied Ecology, \\ North Carolina State University, 127 David Clark Labs, Campus Box 7617, Raleigh, \\ North Carolina 27695-7617, USA \\ Joseph E. Hightower \\ U. S. Geological Survey, North Carolina Cooperative Fish and Wildlife Research Unit, \\ Department of Applied Ecology, North Carolina State University, 127 David Clark Labs, \\ Campus Box 7617, Raleigh, North Carolina 27695-7617, USA
}

\begin{abstract}
Despite extensive management and research, populations of American Shad Alosa sapidissima have experienced prolonged declines, and uncertainty about the underlying mechanisms causing these declines remains. In the springs of 2007 through 2010, we used a resistance board weir and PIT technology to capture, tag, and track American Shad in the Little River, North Carolina, a tributary to the Neuse River with complete and partial removals of lowhead dams. Our objectives were to examine migratory behaviors and estimate weight loss, survival, and abundance during each spawning season. Males typically immigrated earlier than females and also used upstream habitat at a higher percentage, but otherwise exhibited relatively similar migratory patterns. Proportional weight loss displayed a strong positive relationship with both cumulative water temperature during residence time and number of days spent upstream, and to a lesser extent, minimum distance the fish traveled in the river. Surviving emigrating males lost up to $30 \%$ of their initial weight and females lost up to $50 \%$ of their initial weight, indicating there are potential survival thresholds. Survival for the spawning season was low and estimates ranged from 0.07 to 0.17 ; no distinct factors (e.g., sex, size, migration distance) that could contribute to survival were detected. Sampled and estimated American Shad abundance increased from 2007 through 2009, but was lower in 2010 . Our study provides substantial new information about American Shad spawning that may aid restoration efforts.
\end{abstract}

Anadromous American Shad Alosa sapidissima have experienced drastic and prolonged population declines in their native range despite extensive management efforts. American Shad are native to the Atlantic coast of North America, where spawning migrations range from the St. Johns River, Florida, to the St. Lawrence River, Quebec (Limburg et al. 2003). American Shad are relatively large-bodied anadromous species that connect oceans, estuaries, and rivers ecologically by transporting nutrients while functioning as both predators and prey (Leggett and
Whitney 1972; Garman and Macko 1998). Historically abundant, American Shad has supported large commercial fisheries, including coastwide landings that exceeded 20,000 metric tons in the late 1890s (Walburg and Nichols 1967; Hightower et al. 1996; Limburg et al. 2003). However, harvest and population abundance declined dramatically in the early 20th century and has remained at low levels, and recent landings have been in the hundreds of metric tons (Walburg and Nichols 1967; Hightower et al. 1996; Limburg et al. 2003).

\footnotetext{
*Corresponding author: joshua.raabe@gmail.com

${ }^{1}$ Present address: College of Natural Resources; University of Wisconsin-Stevens Point, 800 Reserve Street, Stevens Point, Wisconsin 54418-3897, USA. 
Efforts to restore American Shad populations focus on the anthropogenic factors typically attributed to their declines, in particular overfishing, habitat degradation, and habitat loss due to dams (Hightower et al. 1996; Cooke and Leach 2003; St. Pierre 2003). To reduce overfishing, agencies have implemented stricter harvest regulations, including eliminating the oceanintercept fishery and a Virginia moratorium in the Chesapeake Bay system (Olney and Hoenig 2001; ASMFC 2007). Extensive larval stocking programs are intended to offset decreased egg and larval production due to low spawning stocks or degraded spawning and nursery habitat (Hendricks 2003; Olney et al. 2003; St. Pierre 2003). Providing fish passage, transporting adults, and removing dams are three methods to reconnect American Shad access to historic spawning grounds (Cooke and Leach 2003; Hendricks 2003; St. Pierre 2003; Burdick and Hightower 2006). Signs of restoration success include the return of hatchery-reared fish, increased passage rates, which affect the extent of upstream migrations, and an increase in population sizes from extremely low numbers (Cooke and Leach 2003; Olney et al. 2003; St. Pierre 2003; Burdick and Hightower 2006).

Nevertheless, native American Shad populations remain at historically low levels (Limburg et al. 2003; ASMFC 2007; Limburg and Waldman 2009), indicating a need to further understand fundamental aspects of their biology and identify the underlying mechanisms for their declines. Prior to dam constructions, American Shad migrated hundreds of kilometers upriver to reach spawning grounds (Stevenson 1899). However, the riverwide distribution of spawning American Shad and any potential differences between sexes were not documented in these early reports and are still unknown in many rivers. During these energetically expensive freshwater migrations, American Shad consume minimal prey, resulting in energy and weight loss that can be substantial and lead to spawning mortality (Chittenden 1976; Leggett and Carscadden 1978; Leonard and McCormick 1999). Yet, no known field studies have thoroughly examined individual weight loss or seasonal spawning survival rates and potential factors such as sex, temperature, duration, or distance traveled. Overall, northern populations of American Shad are primarily iteroparous while southern populations are typically semelparous (Leggett and Carscadden 1978), but the influence of spawning mortality on iteroparity rates and population levels is unknown. Leggett et al. (2004) hypothesized that fish passage structures were actually detrimental to the Connecticut River American Shad population as increased migrations may decrease spawning survival, leading to fewer repeat spawning females and an overall reduction in egg production. Based on a simulation model for the Connecticut River, Castro-Santos and Letcher (2010) determined passage through structures could reduce iteroparity rates due to migratory delays and poor downstream passage. However, neither study estimated the potential trade-off between iteroparity rates and accessing upstream reaches that may contain higher quality spawning or nursery habitat. Understanding factors influencing migrations and seasonal spawning survival may provide insight into why American Shad life histories tend to have a latitudi- nal gradient and to fully inform restoration efforts in different systems.

Important questions remain in part due to the difficulty of sampling and recapturing American Shad. As a highly mobile species present in rivers for a relatively short time period (i.e., typically less than 3 months), sampling American Shad is most effective when fish have already migrated and are congregated at known spawning grounds or downstream of dams. Once captured, American Shad can be very sensitive to handling (Hendricks 2003), resulting in mortalities or a "fallback" behavior, where individuals migrate downstream and temporarily or completely abandon spawning migrations (Beasley and Hightower 2000; Bailey et al. 2004; Olney et al. 2006). Radiotelemetry and acoustic telemetry have produced valuable data on American Shad migration and habitat use, but fallback behavior is common and transmitter battery life and expense limit the duration and number of fish studied (Beasley and Hightower 2000; Bailey et al. 2004; Olney et al. 2006).

We used a resistance board fish weir and PIT technology that alleviated some of these sampling issues and were successful in capturing, tagging, and tracking thousands of American Shad in the Little River, North Carolina, in the springs of 2007 through 2010. The fish weir sampled continuously (when properly functioning) and definitively depicted migratory direction, allowing us to monitor immigration, emigration, and fish conditions (e.g., pre- or postspawn condition, weight) relative to seasonal timing and environmental conditions. Passive integrated transponder tags are relatively inexpensive and lack batteries (Prentice et al. 1990), allowing us to tag and monitor thousands of American Shad and other species over the course of the study. We installed PIT antennas to relocate tagged individuals without additional physical handling to monitor migrations and distributions and to develop individual capture histories used in survival modeling (Castro-Santos et al. 1996; Hewitt et al. 2010). Our objectives were to (1) examine the demographics of the Little River American Shad population and its use of restored habitat, (2) estimate and assess whether weight loss and survival of shad were influenced by distance traveled and other factors, and (3) estimate annual shad abundance.

\section{METHODS}

Study site.-The Little River is a fourth-order tributary to the Neuse River, the confluence of which is approximately 212 river kilometers ( $\mathrm{rkm})$ from Pamlico Sound, North Carolina (Figure 1). Three low-head ( $\leq 4 \mathrm{~m}$ in height), run-of-river dams were completely removed from the Little River: Cherry Hospital Dam (rkm 3.7) in 1998, Rains Mill Dam (rkm 37.7) in 1999, and Lowell Mill Dam (rkm 56.2) in 2005. A partially removed, "notched" dam is present at the city of Goldsboro water treatment plant (rkm 7.9) while Atkinson Mill Dam (rkm 82.3) is the lowermost intact, impassable downstream dam. Collier and Odom (1989) noted American Shad likely were able to pass the Cherry Hospital and city of Goldsboro dams during high flow events, but considered Rains Mill Dam impassible. No previous American Shad population estimates exist. 


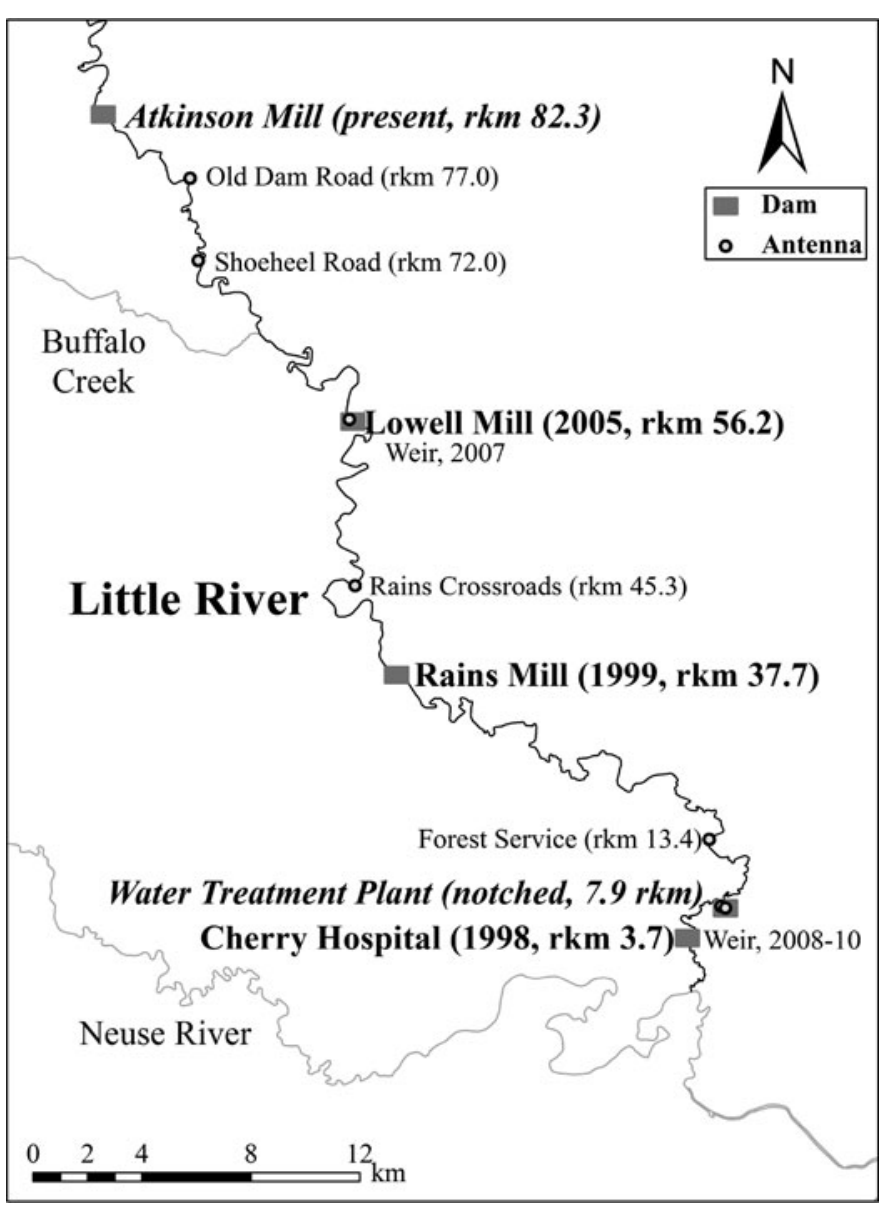

FIGURE 1. The Little River, North Carolina, depicting dam locations and status (year removed, notched, present) and PIT antennas in 2009-2010. The fish weir was located at rkm 56 in 2007 and rkm 4 in 2008-2010.

Fish sampling and tagging.-We used a resistance board fish weir to monitor migrations and capture fish for tagging in the springs (March-May) of 2007 through 2010. The weir was installed at the former Lowell Mill Dam site in 2007 (Figure 1). We installed the weir farther downstream at the former Cherry Hospital Dam site in 2008 through 2010 to encounter and tag immigrating and emigrating fish and monitor their movements with an array of upstream PIT antennas. We constructed the resistance board weir according to Stewart (2002), with minor modifications to target American Shad and accommodate the conditions in the Little River (Raabe 2012). We checked upstream and downstream weir live-cages each morning, evening, and also throughout the day and early night during periods of increased captures. Captured fish were removed with a dip net and brought to shore where they were identified to species, examined to identify sex, measured for TL (mm), and when possible weighed for body mass $(\mathrm{g})$. We examined sex ratios by year, month, and migratory direction, using all individuals sampled at the weir. In 2007, American Shad were tagged near the base of the dorsal fin with individually numbered Hallprint 12/13mm fine T-bar anchor tags. In 2008 through 2010, American Shad received a Texas Instruments PIT transponder (RI-TRP-
RE2B; $3.9 \times 31.2 \mathrm{~mm}, 0.8 \mathrm{~g}$ ). The PIT tags were inserted into the abdominal cavity via a minor incision between the pectoral and pelvic fins; this rapid procedure required no anesthetic. A handheld reader (Allflex Compact Reader RS200) was used to scan all captured fish. We released fish upstream or downstream, depending on their cage of capture.

We used electrofishing to supplement weir captures in 2007 and 2009. A Georator with a portable boom supplied 230 V DC for electrofishing from a small johnboat to capture and T-bar-tag American Shad upstream from the fish weir ( $\mathrm{rkm}$ 56) in 2007. In 2009 we used electrofishing to capture and PIT-tag American Shad during periods of weir failure. We used the Georator unit in middle to lower reaches and conventional electrofishing boats (Smith-Root boat units with pulsed DC [60 Hz, 3.0-4.0 A]) in downstream reaches near the fish weir and river mouth.

PIT antennas.-We installed three PIT antennas in 2008 and four additional antennas in 2009 and 2010 (Figure 1). The PIT antennas were comprised of a Texas Instruments Series 2000 reader, Oregon RFID data logger, two $12-\mathrm{V}$ batteries connected in parallel to power the system, a Texas Instruments tuner box (RI-ACC-008), and a loop of 8-gauge audio cable (Raabe 2012). In all 3 years, when tagged fish migrated upstream from the weir site, the first antenna was located $190 \mathrm{~m}$ downstream from the notched dam at the Goldsboro water treatment plant (rkm 7.7) and a second antenna was installed across the notched dam to monitor fish passage beyond this obstruction (rkm 7.9). In 2009 and 2010, an antenna was installed adjacent to a North Carolina Forest Service facility (rkm 13.4) and upstream from the Rains Mill Dam removal site (rkm 37.7) at Rains Crossroads Road (State Road 2320, rkm 45.3). Another antenna was installed $169 \mathrm{~m}$ upstream from the former Lowell Mill Dam (rkm 56.4) in all 3 years. The final two antennas in 2009 and 2010 were located upstream at Shoeheel Road (State Road 2127, rkm 72.0) and Old Dam Road (State Road 2123, rkm 77.0). Upon weir removal, we relocated an upstream antenna to the weir site (rkm 3.7) to monitor emigrants. We visited antennas every 2 to 4 d to exchange batteries, assure proper tuning, and download data. We estimated seasonal antenna efficiency as the number of detections (upstream and downstream, not repetitive) divided by the total possible detections (Raabe 2012).

Physical measurements.-Onset HOBO-TEMP loggers recorded water temperature $\left({ }^{\circ} \mathrm{C}\right)$ at 1.5 -h intervals at the weir sites. Water gauge height data were obtained from a U.S. Geological Survey (USGS) monitoring station (0208863200) located at Highway 581, immediately downstream from the 20082010 weir site (rkm 3.7). A second USGS monitoring station (02088500), located upstream (rkm 45.3) near Princeton, provided water discharge and gauge height data.

Fish groupings.-To account for weir and antenna inefficiencies (i.e., missed captures and detections) and stress or mortality due to capture, handling, and tagging, we used groupings of American Shad for different analyses. "Sampled" individuals were all American Shad captured at the weir or detected at an antenna. "Immigrating" and "Emigrating" individuals were captured at the weir in 2008-2010 moving in the upstream and 
downstream direction, respectively. "Recaptured" individuals were tagged at the fish weir and later physically recaptured at the fish weir. "Fallback" individuals were tagged at the weir, released upstream, and physically recaptured within $24 \mathrm{~h}$. "Nonrecaptured" individuals were captured at the weir in either the upstream or downstream direction, but were never recaptured at the weir. "Relocated" individuals were tagged at the weir and detected at least once at an antenna. "Repeat" individuals were tagged at the weir in a previous year and were either recaptured at the weir or relocated at an antenna in the Little River in a subsequent year.

To account for potential handling and tagging stress, mortality, or tag loss, we assumed fish tagged and relocated at or upstream from the Forest Service antenna (rkm 13.4) retained their tags and were healthy, "Viable" individuals as they moved nearly $10 \mathrm{rkm}$ after tagging. Tagged individuals relocated near the notched dam (rkm 7.7 and 7.9) moved $4 \mathrm{rkm}$ and may have been healthy but never passed the structure, suffered altered behavior and mortality due to handling and tagging, or lost their tag. We assumed tagged individuals that were never recaptured or relocated lost their tag or suffered handling and tagging mortality, although it is possible they were missed by our sampling gears (e.g., during high flows) or died due to other causes. We attempted to account for potential PIT tag loss by tagging a subset of individuals with both a PIT and external T-bar tag, but our recaptures rates were too low. Abdominal insertion of PIT tags has high retention; therefore, we assumed PIT tag loss was low (Gries and Letcher 2002).

Movement and migrations.-The 2007 weir location (rkm 56.4) provided information on within-river movements, while the close proximity of the weir to the Neuse River in 2008 through 2010 provided information on immigration and emigration events. At the weir, movement direction was determined based on capture location (i.e., upstream movement $=$ upstream live-cage capture). For antennas, we determined an upstream movement to occur when an individual was relocated upstream from its previous capture or detection site and the opposite for downstream movement events. We could not determine whether repetitive, sequential detections at the same antenna were due to an individual remaining near the antenna or moving undetected in the reach between antennas. To characterize movement and migration, we focused on 2009 and 2010 when all antennas were installed for at least half the spawning season. We determined the maximum extent of migrations as the uppermost antenna reached and calculated the total distance traveled $(\mathrm{rkm})$ in the Little River as the sum of the distance between locations for all upstream and downstream movements. Due to potential movements within unsampled reaches, we considered this to be a minimum total distance traveled within the Little River; adding $212 \mathrm{rkm}$ to this total would provide an estimate of total distance traveled in the Neuse and Little rivers. We first examined all relocated individuals and then focused on viable individuals. Using Tukey-Kramer honestly significantly different (HSD) tests, we compared potential differences in TL and weight (by sex) at capture for viable individuals grouped into the maximum extent they reached (e.g., rkm 13.4, 45.3, etc.).

Weight loss.-During American Shad residence in the Little River, we estimated sex-specific changes in body mass (weight loss) for recaptured individuals in 2009 and 2010 and for groups (immigrants compared with emigrants) for nonrecaptured individuals in 2008 through 2010. We examined potential differences between nonrecaptured immigrants and emigrants in total lengths and weights by month and year using Tukey-Kramer HSD tests for multiple comparisons. For tagged individuals recaptured at least $48 \mathrm{~h}$ after release at the fish weir, we computed the weight loss $(\mathrm{g})$ between capture and recapture events and the proportion of weight lost (weight difference / capture weight). Using linear regression, we compared both metrics with time upstream (in days expressed as a decimal number), cumulative thermal days (the aggregate sum of mean daily temperature $\left[{ }^{\circ} \mathrm{C}\right]$ for each day upstream), total minimum distance traveled (rkm), and the TL (mm) and weight ( $\mathrm{g}$ ) at initial capture. We compared models with a corrected Akaike's information criterion $\left(\mathrm{AIC}_{c}\right)$ and regression $R^{2}$-values. For nonrecaptured individuals, we conducted linear regressions for weight at TL separately for immigrants and emigrants. Using these regression equations, we estimated immigration and emigration weight at $5-\mathrm{mm}$ length intervals (minimum to maximum TLs for each sex) and estimated proportional weight loss for each interval. From analyses for both recaptured and nonrecaptured individuals, we examined the proportional weight loss estimates for apparent survival to emigration thresholds (i.e., proportional weight loss value at which few or no emigrating individuals were captured).

Survival.-We estimated American Shad spawning season survival using three methods. For the weir-only method we used only weir captures and estimated survival as

seasonal survival $=$ recaptured emigrants/tagged immigrants,

where fallback individuals were excluded in immigrant and emigrant counts. We calculated this estimate for 2007-2010 and used only fish tagged in that year (i.e., excluded returning fish tagged in a prior year because this did not occur in 2007 and 2008). In the weir and antennas method, we estimated seasonal survival as

$$
\text { seasonal survival }=\text { tagged emigrants/viable individuals, }
$$

where tagged emigrants excluded fallback individuals but included recaptures and individuals with distinct emigration patterns at antennas during nonfunctioning weir periods (i.e., fish that were missed emigrating passed the weir). We calculated this estimate for 2009 and 2010 and included returning individuals (tagged in prior year) if they were detected at least twice, either at rkm 13.4 or upstream antennas. For the third method, we used a state-space Cormack-Jolly-Seber (CJS) model that estimated weekly survival and detection probabilities (Royle 2008; Kéry and Schaub 2012). We used the same individuals as in the weir 
and antenna method. Individual encounter histories depicted whether an individual was sampled at the weir or relocated at antenna (1) or not (0) within 12 weekly periods (March 12-June 3, 2009; March 10-June 1, 2010). Individuals were conditioned on their first capture or detection and we censored emigrating individuals from the model after their last week in the river. Encounter histories were conditional on whether an individual was estimated to be in an alive state $(z=1)$ or not alive or not in the river $(z=0$ : Royle 2008). We ran models with constant and time-dependent survival and detection rates. We fit the CJS models using a Bayesian framework for analysis in open-source software programs, JAGS (Plummer 2003, 2012) and R (R Development Core Team 2012) via the R package "rjags." We ran three chains with an adaptive phase of 10,000 iterations and evaluated output from an additional 20,000 iterations. Our final model had constant survival and detection rates as it depicted stable posterior distributions, and no discernible patterns existed in models with time-dependent rates. We extended the weekly survival estimate to 12 weeks to estimate seasonal survival.

We examined potential factors influencing survival using descriptive statistics, logistic regression, and contingency tests. We calculated the time at large (difference between first and last observations) and the distribution for the last known river location of all relocated individuals. We plotted tagged fish locations across time to visually determine whether individuals initiated downstream movement from their maximum upstream reach. We then assessed whether individuals successfully emigrated or died in either their maximum upstream reach or during an apparent downstream migration. For individuals detected at rkm 13.4 or above, we used logistic regression and contingency tests to examine potential relationships between documented survival $(0=$ recaptured and/or emigrated) and apparent mortality (1) with day and week of entry, time at large, maximum upstream extent, total distance traveled, and cumulative flow and thermal days (the aggregate sum of daily mean temperatures for each day at large).

To determine whether American Shad returned to spawn in subsequent years and examine annual survival rates, we scanned all fish captured in the Little River for PIT tags in 2009 through 2010. North Carolina Wildlife Resources Commission fisheries biologists scanned for PIT tags in all American Shad captured in the Neuse River in 2009 and 2010.

Abundance.-We considered the minimum annual American Shad abundance to be the number of individuals sampled plus any repeat individuals only relocated at antennas and also estimated a total number to account for individuals missed at the weir. We assumed that the Little River population was separate from the Neuse River population. In addition to fish captured at the weir, we included electrofishing sampling in 2007 and 2009 and returning individuals that were recaptured or detected in 2009 and 2010. Some individuals that migrated upstream past the weir during failure periods were accounted for when captured during their emigration, but others were unsampled if they either died upstream or also emigrated during weir failures. We estimated the annual abundance as

$$
\begin{aligned}
& \text { annual abundance } \\
& =\text { sampled }+ \text { repeat }+(\text { emigrating nonrecaptures } \\
& \quad \text { / survival estimate })
\end{aligned}
$$

where "sampled" excluded recaptures and we used the weir-only annual apparent survival estimate.

We compared the annual sampled and estimated American Shad run sizes within the Little River to two guideline estimates for healthy populations. These guidelines are estimated from the amount of available main-stem river habitat and commonly used for carrying capacity estimates during dam relicensing procedures and to set restoration goals. The most widely used rule-ofthumb value of 124 American Shad/ha is based on historical data for the Susquehanna and Connecticut rivers (St. Pierre 1979). St. Pierre (1979) stated that these projections were estimates of the potential size of a fully restored run in large rivers, but also emphasized that the estimates were only a first approximation based on numerous assumptions. Savoy and Crecco (1994) produced a guideline of 49 American Shad/ha from more recent population estimates for the Connecticut River. We used this value as a more conservative estimate of a restored population. To determine the amount of available main-stem Little River habitat, we outlined the bank-full river channel from an aerial photograph layer in ArcGIS 10.0 (ESRI 2010), created polygons for each reach (described above), and computed the area (ha).

\section{RESULTS}

\section{Demographics}

We sampled a total of 5,085 American Shad at the weir from 2007 through 2010 (Table 1). The fewest American Shad were captured in 2007 when the weir was in place upstream (rkm 56.4), while the most American Shad were captured in 2009 despite the weir functioning for the fewest days. In 2007 through 2009 , we captured a substantial number of nonrecaptured emigrants that immigrated prior to weir installation or during weir failures. In 2010 we captured more immigrants than emigrants.

TABLE 1. Total number of American Shad sampled (including recaptures) and number of functioning sampling days at the fish weir from 2007 to 2010 in the Little River.

\begin{tabular}{ccccr}
\hline & & \multicolumn{3}{c}{ American Shad captured } \\
\cline { 3 - 5 } Year & Sampling days & Upstream & Downstream & Total \\
\hline 2007 & 64 & 46 & 441 & 503 \\
2008 & 61 & 137 & 1,003 & 1,145 \\
2009 & 50 & 474 & 1,723 & 2,197 \\
2010 & 70 & 853 & 387 & 1,240 \\
Total & 245 & 1,510 & 3,554 & 5,085 \\
\hline
\end{tabular}


TABLE 2. Female : male sex ratio (sample size in parentheses) of American Shad relative to year, upstream and downstream capture, and month in the Little River. Fish weir was located at rkm 56.4 in 2007 and rkm 3.7 in 2008 through 2010.

\begin{tabular}{|c|c|c|c|c|}
\hline & 2007 & 2008 & 2009 & 2010 \\
\hline \multicolumn{5}{|c|}{ Upstream } \\
\hline March & $0.75(7)$ & $0.74(33)$ & $0.51(62)$ & 0.37 (491) \\
\hline April & $0.32(29)$ & $0.56(89)$ & $1.26(167)$ & 0.89 (183) \\
\hline May & $0.67(10)$ & $0.75(7)$ & $1.80(230)$ & $1.43(165)$ \\
\hline Total upstream & $0.44(46)$ & $0.61(129)$ & 1.33 (459) & $0.60(839)$ \\
\hline \multicolumn{5}{|c|}{ Downstream } \\
\hline March & 0.00 (4) & $0.86(26)$ & $0.67(5)$ & $0.60(8)$ \\
\hline April & $1.19(226)$ & $1.01(632)$ & $1.63(189)$ & $1.15(103)$ \\
\hline May & 0.49 (191) & $0.87(305)$ & $1.41(1,359)$ & $1.36(106)$ \\
\hline Total downstream & $0.79(421)$ & $0.96(963)$ & $1.43(1,553)$ & $1.23(217)$ \\
\hline Grand total & $0.76(467)$ & $0.91(1,092)$ & $1.41(2,012)$ & $0.71(1,056)$ \\
\hline
\end{tabular}

The annual female to male sex ratio ranged from 0.71 in 2010 to 1.41 in 2009 (Table 2; Figure 2). In all 4 years, males were more common in both upstream and downstream March captures and were generally more common in all 2007 captures when the weir was located upstream. Females were consistently more abundant in downstream catches in April in all 4 years and were generally more common in April and May of 2009 and 2010.

Although the weir effectively captured American Shad, handling and tagging did influence individuals and fish were missed at both the weir and the antennas. Poor condition and mortality was high in the upstream live-cage in 2007 and 2008 (24-31\%) but much lower in 2009 and 2010 (4-8\%) when we checked the weir more frequently. We only PIT-tagged visibly healthy individuals. However, fallback behavior was still an issue; the highest number of fallback individuals (15\%) occurred in 2008 and the lowest (9\%) occurred in 2010. Only a few fallback individuals (one in 2009, seven in 2010) were later recaptured or relocated. In 2009 and 2010, 30-34\% of PIT-tagged individuals were never recaptured or relocated (maximum handling and tagging mortality estimate) compared with $40 \%$ recaptured in 2008 when there were fewer antennas. Fish were missed at both the weir and the antennas, primarily during high flow periods (see Raabe 2012 for more details). Seasonal antenna detection efficiency ranged from 0.76 to 0.82 in 2009 and 0.70-0.95 in 2010; exceptions were at rkm 56.4 in $2009(0.20$, technical problems) and rkm 7.9 in 2010 (0.17, installation issues).

\section{Movement and Migrations}

American Shad were captured at the weir as they immigrated and emigrated from March through May, and increased captures occurred during high flow periods (Figure 2). Water temperatures for immigrants ranged from $9.6^{\circ} \mathrm{C}$ on March 16, 2009, to $24.1^{\circ} \mathrm{C}$ on May 15, 2010. Distinct immigration events occurred during freshets prior to weir failures in late March to early April in 2008, early May 2009, and both mid-March and the end of March in 2010. Males dominated the immigration events in 2008 and 2010, but females dominated the 2009 event. American Shad primarily emigrated in mid-April through mid-May. A large downstream movement event in 2007 occurred during low flows when water temperatures rose to $22.8^{\circ} \mathrm{C}$. In 2008 and 2009, large emigration events occurred during freshets in late April to early May; mean daily water temperatures typically exceeded $20^{\circ} \mathrm{C}$. Few individuals were captured emigrating in 2010, and no distinct emigration events occurred.

Male and female American Shad migrated into the upper extent of restored habitat in the Little River, but the terminal reach for many individuals was in downstream and middle reaches in both 2009 and 2010 (Figure 3). A large percentage of females ( $>40 \%$ ) ended their migration between $\mathrm{rkm} 7.7$ and 13.4, which included the Goldsboro notched dam at rkm 7.9, whereas a higher percentage of males appeared to end their migrations in the long reach between rkm 13.4 and 45.3. However, a noticeable percentage of individuals migrated into reaches upstream from rkm 45.3, and males more commonly accessed the uppermost reach downstream from Atkinson Mill Dam (rkm 77.0-82.3). No significant differences $(P>0.05)$ were detected between terminal reaches and the TL or weight at capture of females in 2009 and males in 2009 and 2010. In 2010, female weight at capture was significantly higher $(P=0.015)$ in the uppermost reach ( $\mathrm{rkm} 72.0-82.3$; mean $=1,456.3 \mathrm{~g}, \mathrm{SE}=62.22)$ compared with the lower to middle reach (rkm 13.4-45.3; mean = $1,220.2 \mathrm{~g}, \mathrm{SE}=35.10$ ), but no other significant differences were identified for females in 2010.

No American Shad captured by electrofishing in the Neuse River upstream from the Little River confluence in $2009(n=$ 293) or $2010(n=365)$ contained a PIT tag. This indicates these fish did not spend time in the Little River in the previous or current year of capture. It also provides some support to our assumption about abundance estimates in that American Shad in the Little River is a separate population. 


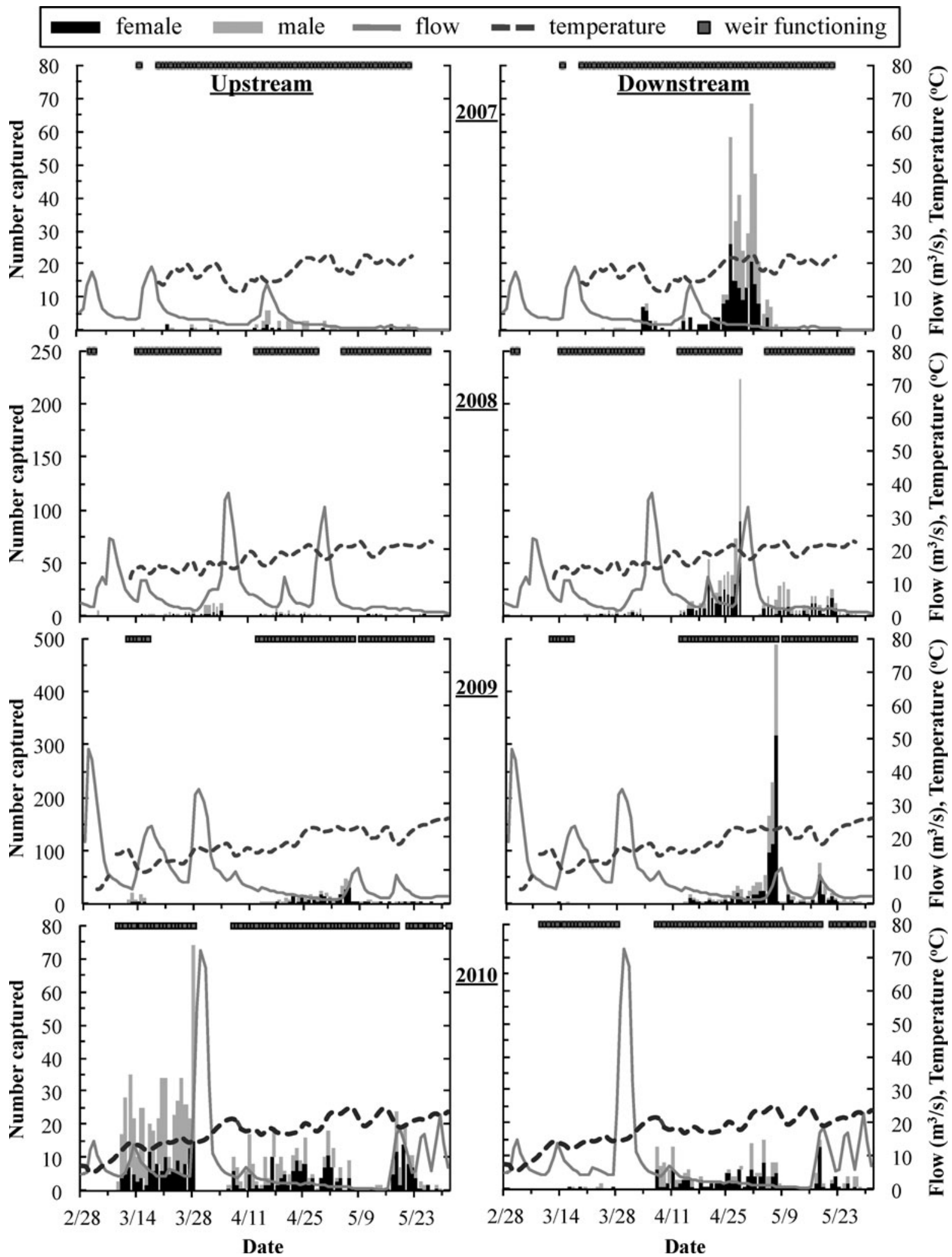

FIGURE 2. Upstream and downstream captures of female and male American Shad relative to flow and water temperature at the Little River fish weir located at rkm 56.4 in 2007 and rkm 3.7 in 2008-2010. Dates are given as month/day. 


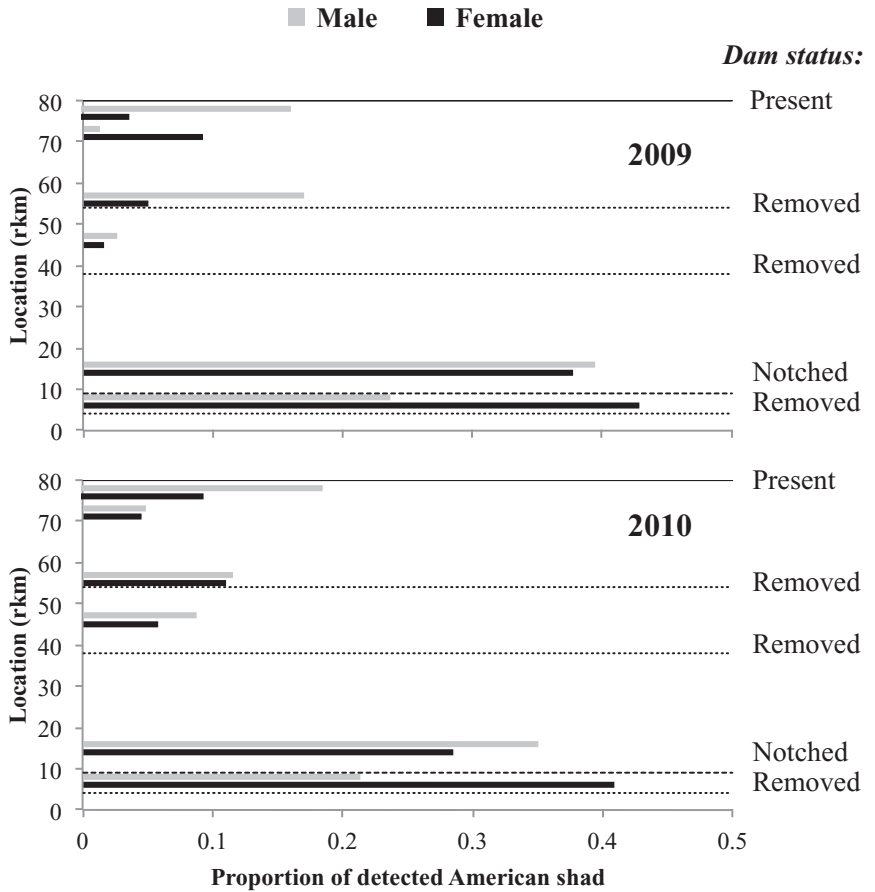

FIGURE 3. Distribution of maximum upstream detections of male and female American Shad in the Little River in 2009 and 2010 relative to removed, notched, and present dams.

\section{Weight Loss}

Female American Shad ranged from 385 to $575 \mathrm{~mm}$ in TL (mean $=481.5 \mathrm{~mm}, \mathrm{SE}=0.67, n=1,328)$ whereas males ranged from 346 to $515 \mathrm{~mm}$ (mean $=425.5 \mathrm{~mm}, \mathrm{SE}=0.70$, $n=1,343$ ). Weight for immigrants ranged from 446 to $1,956 \mathrm{~g}$ for females (mean $=1,240.4 \mathrm{~g}, \mathrm{SE}=10.3, n=582$ ) and from 350 to $1,265 \mathrm{~g}$ for males (mean $=763.4 \mathrm{~g}, \mathrm{SE}=6.28, n=734$ ). A few significant differences occurred between years (20082010) for TL and weight based on migratory direction for both sexes. However, these differences could be a result of when the majority of American Shad were captured each year (Figure 2); when the data from the 3 years were combined, results indicated that larger individuals tended to be captured earlier in the season (Table 3). In particular, mean weight for immigrants significantly decreased from March through May for both sexes. For immigrants both sexes were longer in mean TL in March but similar in length in April and May. Similar patterns existed for emigrants, although very few individuals were sampled in March.

For individuals recaptured after $48 \mathrm{~h}$ in 2009 and 2010, male weight loss ranged from 12 to $264 \mathrm{~g}$ (mean $=88.9 \mathrm{~g}, \mathrm{SE}=15.11$, $n=23$ ) while females lost between -3 (slight gain) and $984 \mathrm{~g}$ (mean $=307.7 \mathrm{~g}, \mathrm{SE}=37.56, n=40$ ). The proportion of weight lost ranged from 0.01 to 0.33 (mean $=0.12, \mathrm{SE}=0.020$ ) for males compared with $0-0.64$ (mean $=0.24, \mathrm{SE}=0.25)$ for females (Figure 4). We examined proportion of weight loss further as it appeared to be a better response variable (e.g., higher $R^{2}$ )
TABLE 3. Total length ( $\mathrm{mm})$ and weight $(\mathrm{g})$ of female and male American Shad measured in 2008 through 2010. Different lowercase letters represent significant differences $(P<0.05)$ among months within the grouping.

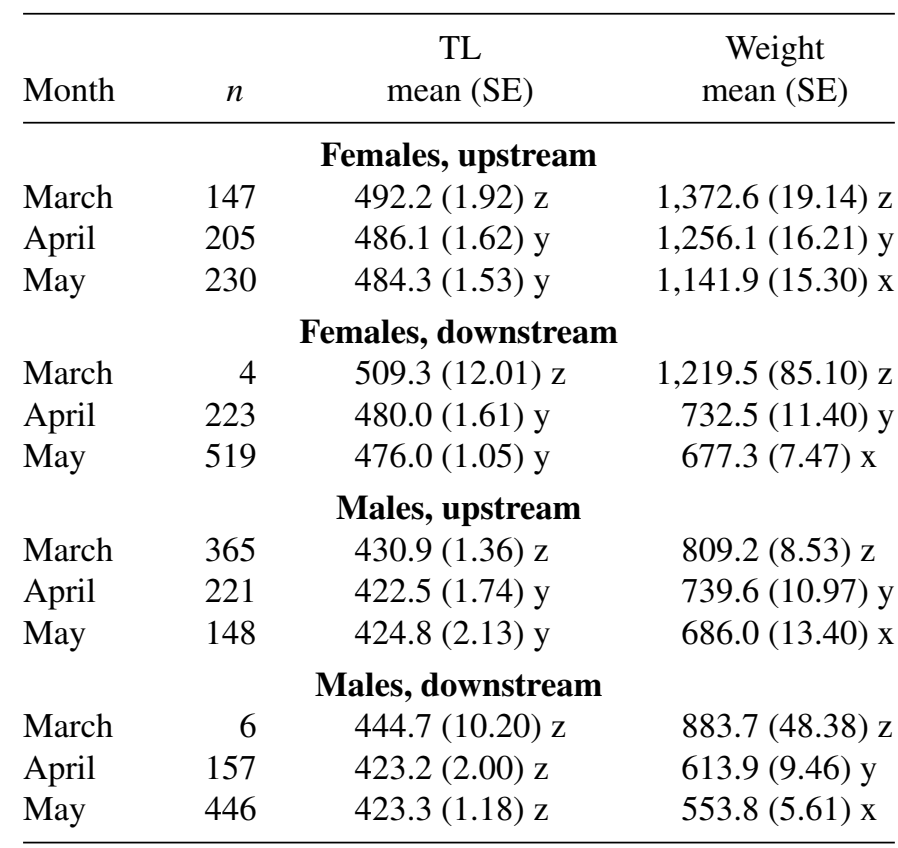

than total weight loss in regression analyses (Table 4; Figure 4). For both sexes, proportion of weight loss displayed a strong, positive response to cumulative thermal days and time spent upstream (these metrics were highly correlated). Cumulative minimum distance traveled also showed a positive relationship with proportional weight loss but explained less of the variation. No relationships existed between proportional weight loss and the TL or weight at immigration, even when including thermal days or time upstream in multiple regression analyses.

Weight relationships for immigrants and emigrants displayed similar patterns for nonrecaptured American Shad (Figure 5). Emigrants weighed significantly less than immigrants for both males (mean upstream $=763.4 \mathrm{~g}, \mathrm{SE}=5.59$; mean downstream $=572.5, \mathrm{SE}=6.13 ; P<0.0001)$ and females (mean upstream $=1,240.4 \mathrm{~g}, \mathrm{SE}=8.75$; mean downstream $=$ 696.8, $\mathrm{SE}=7.74 ; P<0.0001)$. Estimated proportional weight loss determined from length-weight regressions ranged from 0.09 (at $345 \mathrm{~mm}$ ) to 0.26 (at $515 \mathrm{~mm}$ ) for males (mean $=0.21$, $\mathrm{SE}=0.008$ ) and 0.38 (at $575 \mathrm{~mm}$ ) to 0.48 (at $385 \mathrm{~mm}$ ) for females (mean $=0.41, \mathrm{SE}=0.003)$.

\section{Survival}

All three methods estimated a low spawning season survival rate for American Shad in the Little River (Table 5). All estimates are considered to be a minimum, or apparent, survival rate because individuals potentially emigrated without being captured during weir failure periods. In the weir-only method, survival was highest in 2007, but it is unknown whether individuals survived from this upstream weir location ( $\mathrm{rkm} 56.4$ ) to the 
TABLE 4. Results from simple linear regression models examining the relationship between proportional weight loss and different potential factors for male and female American Shad recaptured after two or more days upstream from the Little River fish weir in 2009 and 2010.

\begin{tabular}{|c|c|c|c|c|c|c|c|}
\hline \multirow[b]{2}{*}{ Factor } & \multirow[b]{2}{*}{$\mathrm{AIC}_{c}$} & \multirow[b]{2}{*}{$\Delta \mathrm{AIC}_{c}$} & \multirow[b]{2}{*}{$R^{2}$} & \multicolumn{2}{|c|}{ Intercept } & \multicolumn{2}{|c|}{ Coefficient } \\
\hline & & & & Estimate & $P$-value & Estimate & $P$-value \\
\hline \multicolumn{8}{|c|}{ Females $(n=40)$} \\
\hline Cumulative thermal days $\left({ }^{\circ} \mathrm{C}\right)$ & -110.80 & 0.00 & 0.88 & 0.0570 & 0.000 & 0.0062 & $<0.001$ \\
\hline Time upstream $(\mathrm{d})$ & -104.32 & 6.48 & 0.85 & 0.0770 & $<0.001$ & 0.0116 & $<0.001$ \\
\hline Minimum distance traveled (rkm) & -48.15 & 62.65 & 0.40 & 0.1780 & $<0.001$ & 0.0026 & $<0.001$ \\
\hline Capture TL (mm) & -28.05 & 82.74 & 0.02 & -0.1583 & 0.751 & 0.0008 & 0.751 \\
\hline Capture weight (g) & -30.22 & 80.58 & 0.07 & 0.0300 & 0.816 & 0.0002 & 0.103 \\
\hline \multicolumn{8}{|c|}{ Males $(n=23)$} \\
\hline Cumulative thermal days $\left({ }^{\circ} \mathrm{C}\right)$ & -89.33 & 0.00 & 0.90 & 0.0165 & 0.107 & 0.0004 & $<0.001$ \\
\hline Time upstream (d) & -77.70 & 11.64 & 0.83 & 0.0317 & 0.014 & 0.0066 & $<0.001$ \\
\hline Minimum distance traveled (rkm) & -56.23 & 33.11 & 0.58 & 0.0786 & $<0.001$ & 0.0023 & $<0.001$ \\
\hline Capture TL (mm) & -36.81 & 52.52 & 0.02 & 0.3714 & 0.317 & -0.0006 & 0.491 \\
\hline Capture weight (g) & -36.35 & 52.98 & $<0.01$ & 0.1412 & 0.157 & $<0.0001$ & 0.806 \\
\hline
\end{tabular}

\section{O Female $\triangle$ Male}
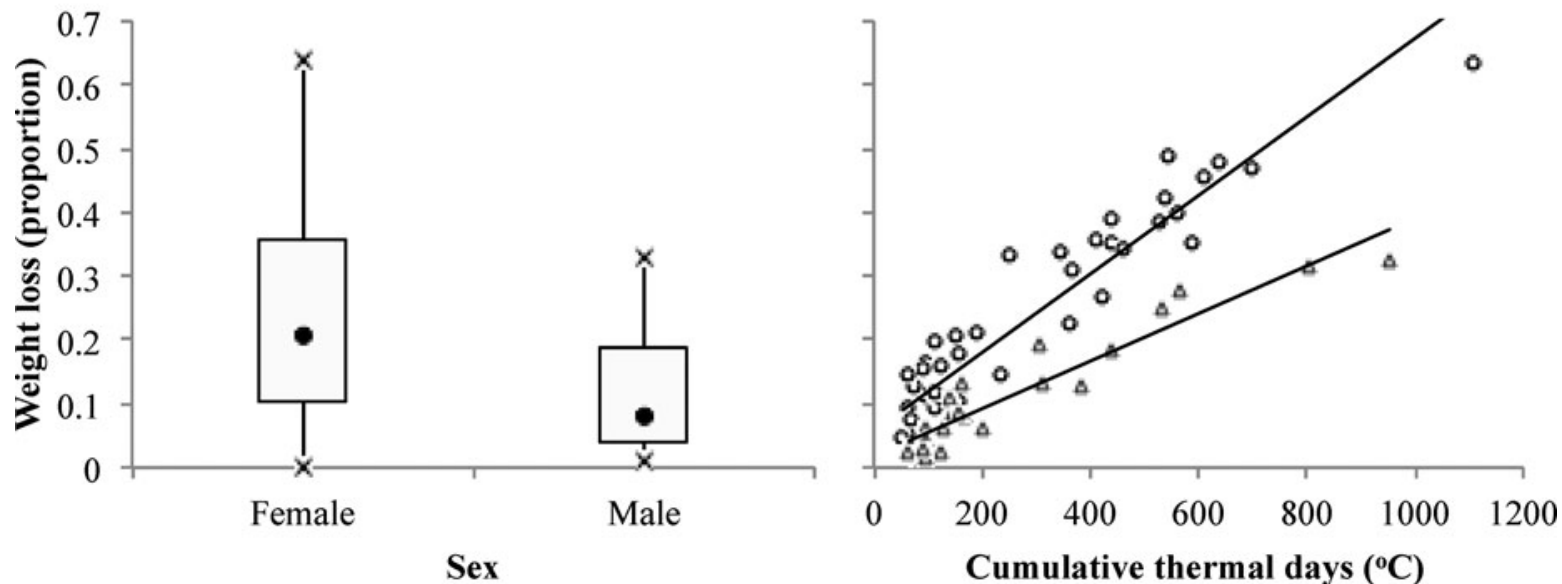

Sex

Cumulative thermal days $\left({ }^{\circ} \mathrm{C}\right)$
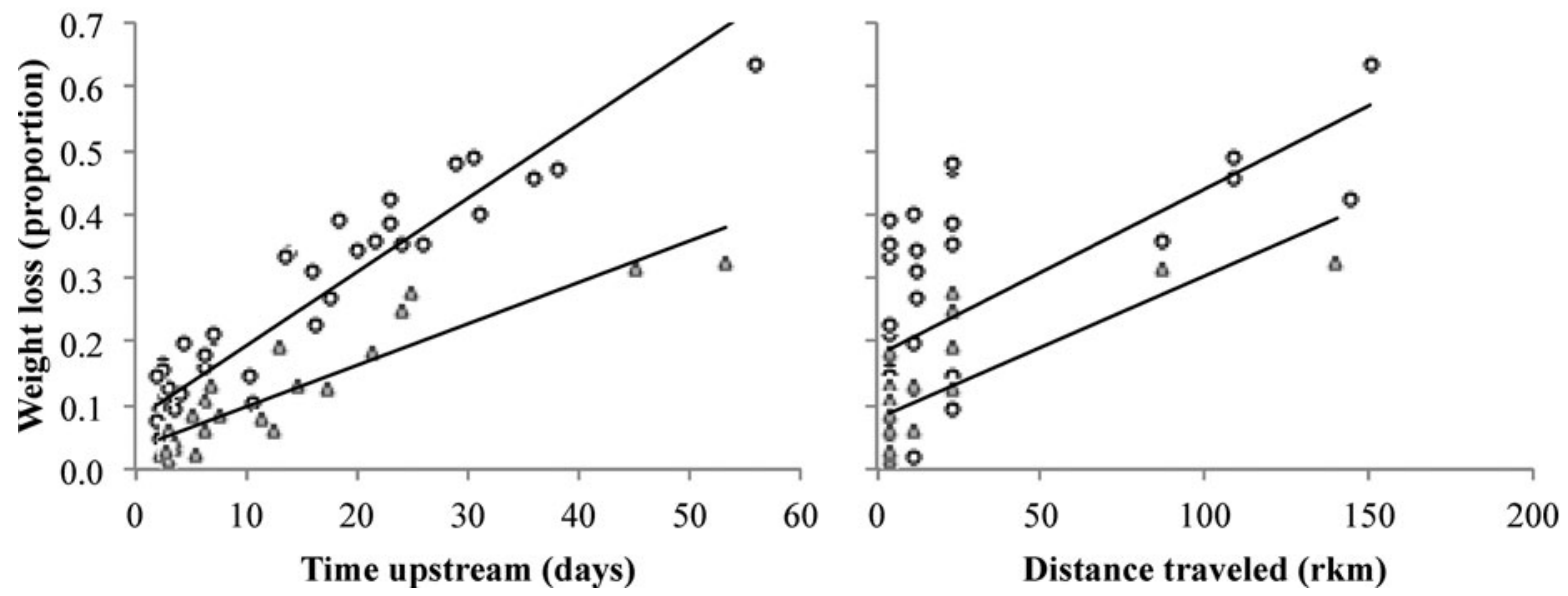

FIGURE 4. Relationships between a variety of factors and proportion of weight loss for male and female American Shad recaptured after two or more days upstream from the Little River fish weir in 2009 and 2010. 


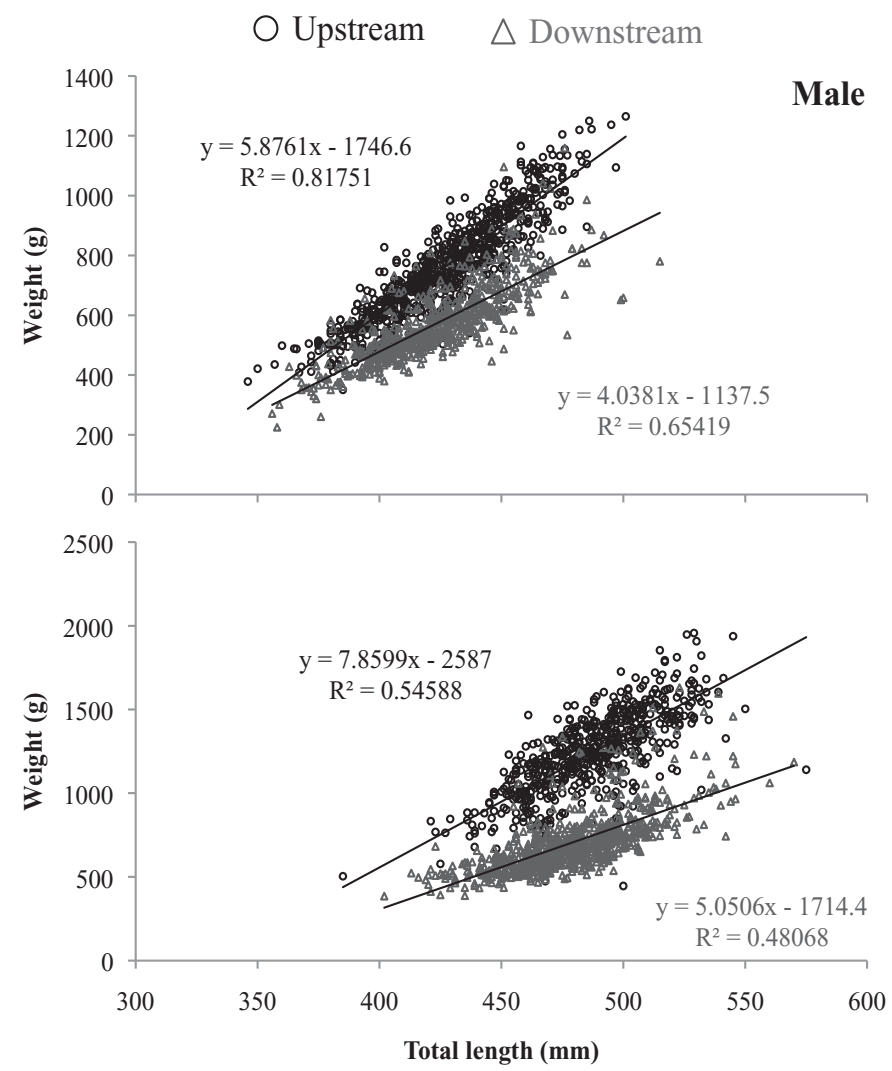

FIGURE 5. Length-weight relationships for female and male American Shad captured immigrating into and emigrating from the Little River in 2008 through 2010. Recaptured American Shad were excluded from both upstream and downstream groupings.

downstream weir location (rkm 3.7) used in other years. When considering only viable individuals and accounting for relocated individuals that were clearly missed at the weir, estimated survival rates decreased slightly in both 2009 and 2010. Weekly survival estimates according to the CJS model also depicted higher survival in 2009 (mean $=0.847,95 \%$ credible interval $=$ $0.797-0.895$ ) than in 2010 (mean $=0.814,95 \%$ credible inter$\mathrm{val}=0.791-0.836$ ) but were within the margins of uncertainty. Mean weekly detection probabilities were slightly lower in 2009 (mean $=0.515,95 \%$ credible interval $=0.445-0.584)$ than in
$2010($ mean $=0.577,95 \%$ credible interval $=0.541-0.612)$, but also within the margins of uncertainty. The CJS survival estimates were comparable with the other seasonal estimates when extended to 12 weeks residence in the river (Table 5).

We documented repeat spawning of American Shad in the Little River, but at very low numbers, even when we considered potential stressors and mortality due to handling and tagging. Eight individuals tagged in 2008 returned in 2009, and six tagged in 2009 returned in 2010. Within-season survival was considerably higher for the eight repeat individuals in 2009 (0.625), but none of the six repeat individuals in 2010 were documented emigrating. One repeat American Shad was captured at the weir in 2010 but was never detected at the antennas, while one 2009 and two 2010 repeat individuals were not captured (i.e., no handling or tagging) but were relocated only once.

Many American Shad apparently died in their terminal reach as they did not appear to initiate a downstream movement in 2009 and 2010, but those that did typically migrated near or past the weir site regardless of their extent of upstream migration (Table 6). A large proportion of males and females apparently died between rkm 7.7 and 45.3 in both years and between rkm 45.3 and 56.4 in 2010. For individuals that initiated a downstream movement, most reached at least the antenna at rkm 7.7 or were recaptured in 2009 , but a lower proportion appeared to successfully emigrate in 2010.

American Shad displayed no strong distinctions between individuals that survived to emigrate from the Little River and those that apparently died upstream. For viable individuals in 2009 and 2010, a similar proportion of tagged males (0.09) and females $(0.10)$ successfully emigrated. Contingency analyses indicated significant differences (Pearson $<0.05$ ) for survival by week in 2009 and 2010, but results were suspect due to low sample sizes in certain weeks, and survival did not display a significant relationship $(P>0.30)$ with the date of entry in either 2009 or 2010 in logistic regression analyses. For both years combined, a contingency analysis showed no relationship $($ Pearson $=0.99)$ between survival and the maximum upstream extent reached, as survival rates ranged from 0.085 at rkm 77.0 to 0.108 at rkm 44.0. On average, emigrating individuals migrated a greater total minimum distance $($ mean $=73.2 \mathrm{rkm}, \mathrm{SE}=5.22, n=41)$ than did individuals that apparently died in the river (mean $=42.0$

TABLE 5. American Shad spawning season survival estimates in the Little River from 2007 through 2010 . The weir method used tagged individuals that remained upstream for at least $24 \mathrm{~h}$; the weir-and-antenna method and Cormack-Jolly-Seber (CJS) model method used only individuals detected at rkm 13.4 or upstream. SE-values for weekly CJS estimates were 0.00042 in 2009 and 0.00009 in 2010.

\begin{tabular}{|c|c|c|c|c|c|c|c|c|}
\hline \multirow[b]{2}{*}{ Year } & \multicolumn{3}{|c|}{ Weir (upstream > 24 h) } & \multicolumn{3}{|c|}{ Weir and antennas ( $\geq$ rkm 13.4) } & \multicolumn{2}{|c|}{ Weekly CJS } \\
\hline & Tagged $(n)$ & Recaptured ( $n)$ & Estimate & Relocated $(n)$ & Emigrated $(n)$ & Estimate & Estimate & 12 weeks \\
\hline 2008 & 82 & 8 & 0.098 & & & & & \\
\hline 2009 & 364 & 60 & 0.165 & 124 & 18 & 0.145 & 0.847 & 0.136 \\
\hline 2010 & 703 & 59 & 0.084 & 315 & 23 & 0.073 & 0.814 & 0.085 \\
\hline
\end{tabular}


TABLE 6. Proportion of male and female American Shad initiating a downstream movement and subsequently reaching rkm 7.7 or downstream relative to their maximum upstream reach in 2009 and 2010 in the Little River.

\begin{tabular}{|c|c|c|c|c|c|c|c|c|c|c|c|c|}
\hline \multirow[b]{2}{*}{ Reach (rkm) } & \multicolumn{3}{|c|}{ Females 2009} & \multicolumn{3}{|c|}{ Males 2009} & \multicolumn{3}{|c|}{ Females 2010} & \multicolumn{3}{|c|}{ Males 2010} \\
\hline & $n$ & Initiated & $\leq \mathrm{rkm} 7.7$ & $n$ & Initiated & $\leq \mathrm{rkm} 7.7$ & $n$ & Initiated & $\leq \mathrm{rkm} 7.7$ & $n$ & Initiated & $\leq \mathrm{rkm} 7.7$ \\
\hline 7.7-13.4 & 50 & 0.22 & 0.22 & 18 & 0.22 & 0.22 & 63 & 0.13 & 0.13 & 61 & 0.11 & 0.11 \\
\hline $13.4-45.3$ & 45 & 0.24 & 0.24 & 30 & 0.27 & 0.27 & 44 & 0.11 & 0.11 & 100 & 0.04 & 0.04 \\
\hline $45.3-56.4$ & 2 & 0.50 & 0.50 & 2 & 0.50 & 0.50 & 9 & 0.11 & 0.11 & 25 & 0.16 & 0.08 \\
\hline $56.4-72.0$ & 6 & 0.17 & 0.17 & 13 & 0.08 & 0.08 & 17 & 0.41 & 0.29 & 33 & 0.33 & 0.09 \\
\hline $72.0-77.0$ & 11 & 0.09 & 0.09 & 1 & 0.00 & 0.00 & 7 & 0.00 & 0.00 & 14 & 0.43 & 0.14 \\
\hline $77.0-82.3$ & 4 & 0.00 & 0.00 & 12 & 0.33 & 0.17 & 14 & 0.29 & 0.07 & 52 & 0.23 & 0.10 \\
\hline
\end{tabular}

$\mathrm{rkm}, \mathrm{SE}=1.67, n=399)$, but survival and total distance traveled did display a significant $(P<0.0001)$ negative, but weak (e.g., $\left.R^{2}<0.1\right)$ relationship in logistic regression. Duration in the river ranged from 1.8 to $74.9 \mathrm{~d}$ for emigrating individuals (mean $=$ $33.0 \mathrm{~d}, \mathrm{SE}=3.17, n=41)$ and from 0.1 to $88.3 \mathrm{~d}$ (mean $=18.0$ $\mathrm{d}, \mathrm{SE}=0.87, n=399$ ) for individuals that apparently died in the Little River. Duration in the river, along with other cumulative metrics (e.g., sum during residence of discharge, temperature) and mean temperature during residence displayed weak (e.g., $R^{2}$ $<0.1)$ but significant $(P<0.0001)$, negative logistic relationships with survival. Survival displayed positive, significant $(P$ $<0.02$ ) but very weak (e.g., $R^{2}<0.03$ ) relationships with mean river conditions (e.g., discharge, gauge height) during residence.

\section{Abundance}

The number of sampled and estimated American Shad increased from 2007 through 2009, but estimated abundance decreased in 2010 (Table 7). Electrofishing slightly supplemented weir captures in $2007(n=23)$ and $2009(n=17)$. In both 2009 and 2010, five repeat individuals only detected at antennas were added to the total number sampled. The fewest American Shad were sampled in 2007; however, when we accounted for the upstream weir location (divided total sampled by the proportion [0.31] that migrated to rkm 56.4 or farther upstream in 2010), the estimate was higher than the number sampled in 2010. Estimated abundance exceeded the 49-shad/ha guideline in 2008 and 2009 but was still at least $50 \%$ lower than the 124-shad/ha rule-of-thumb estimate. The estimated abundance for 2010 was noticeably lower than for other years.

\section{DISCUSSION}

\section{Migratory Behavior}

American Shad were present in the Little River from March through May in all 4 years. During these months, water temperatures were usually within the $8-26^{\circ} \mathrm{C}$ range for spawning activity as reported by Walburg and Nichols (1967). Duration in the river may vary widely for individuals that emigrate (longest recapture duration $=75 \mathrm{~d}$ ) as well as for those that die in the river (longest relocation duration $=88 \mathrm{~d}$ ); it is unknown how long individuals resided in areas not sampled by antennas. In all years, individuals primarily emigrated from the Little River after mean daily water temperatures remained above $20^{\circ} \mathrm{C}$, suggesting individuals waited to spawn until the optimal range of 14-22 ${ }^{\circ} \mathrm{C}$ was attained (Walburg and Nichols 1967; Hightower et al. 2012).

Male and female American Shad exhibited similar migratory behaviors and distributions, although males tended to immigrate earlier and use upstream habitat at a higher percentage. Previous studies have also noted that males were more abundant early in the season until female numbers increased or exceeded males in the middle and later portions (Walburg and Nichols 1967; Chittenden 1975). Little River seasonal female-to-male sex ratios ranged from 0.76 in 2007 to 1.41 in 2009. Sex ratios were likely confounded by temporal differences in weir

TABLE 7. Number of sampled and estimated American Shad in 2007 through 2010 in the Little River compared with guidelines recommended for healthy populations (based on number of fish/ha). Any individuals that entered the river but did not migrate to the weir would not have been sampled. The impassable Atkinson Mill Dam (rkm 82.3) represented the upper extent of available habitat.

\begin{tabular}{|c|c|c|c|c|c|c|c|c|}
\hline \multirow[b]{2}{*}{ Reach } & \multirow[b]{2}{*}{ Length (rkm) } & \multirow[b]{2}{*}{ Area (ha) } & \multicolumn{2}{|c|}{ Guideline } & \multicolumn{4}{|c|}{ American Shad sampled (estimated) } \\
\hline & & & 49/ha & 124/ha & 2007 & 2008 & 2009 & 2010 \\
\hline Mouth-dam & 82.3 & 184.0 & 9,016 & 22,814 & & & & \\
\hline Weir-dam ${ }^{\mathrm{a}}$ & 25.9 & 51.1 & 2,504 & 6,342 & $508(1,855)$ & & & \\
\hline Weir-dam ${ }^{b}$ & 78.5 & 174.9 & 8,570 & 21,692 & $(5,984)$ & $1,121(9,899)$ & $2,084(10,155)$ & $1,078(3,512)$ \\
\hline
\end{tabular}

${ }^{\text {a }}$ Located at rkm 56.4 in 2007.

${ }^{\mathrm{b}}$ Located at rkm 3.7 in 2008-2010. 
efficiency, schooling behaviors, and variability in environmental conditions. The weir did not appear to have any selection bias as a wide range of sizes of both sexes were captured throughout the sampling periods. When functioning properly, the weir sampled continuously rather than producing a temporal snapshot as is provided by traditional gears that can have size and sex selectivity biases. For example, in the adjacent Neuse River from 2000 to 2005 males were more common in electrofishing surveys (female : male ratio $=0.3-0.8$ ) but females were more common in gill-net surveys (female : male ratio $=4.0$ 20.2; ASMFC 2007); these differences may be due to the habitat sampled or gear size selectivity. In the Little River, both sexes moved past an antenna at rkm 77.0, indicating the use of habitat restored by dam removals; Collier and Odom (1989) suggested American Shad can only pass the Cherry Hospital and city of Goldsboro dams during high flows and that Rains Mill Dam was impassible. General distribution patterns were similar between sexes, although more females remained downstream (rkm 7.713.4) while more males migrated into the uppermost reach (rkm 77.0-82.3) in both 2009 and 2010. Our analyses did not suggest a relationship between size and maximum extent of migrations. It is possible differences between sexes may be a result of when males and females entered the river, especially relative to the timing of freshets.

Flow conditions appeared to influence American Shad migrations and behavior in the Little River. Raabe (2012) determined a significant, positive relationship between the daily flow (gauge height, discharge) and number of American Shad captures and relocations in the Little River, with a potential decline at the highest flow conditions. Weaver et al. (2003) also observed a positive trend between annual mean discharge and fishway passage for American Shad on the James River, Virginia. Increasing flows likely serve as a migratory cue and may assist individuals migrating in the Neuse River with locating and entering the Little River (Jonsson 1991; Jowett et al. 2005). Anecdotally, we captured the most American Shad in 2009 when three large freshets occurred in March through early April.

American Shad may spawn when conditions are ideal or while they gradually move upstream, but they move rapidly during increased flows. American Shad may move during freshets in search of optimal spawning habitat that includes gravel, cobble, boulder, and bedrock substrates, depths between 1.5 and $4.0 \mathrm{~m}$, and velocities above $0.6 \mathrm{~m} / \mathrm{s}$ (Hightower et al. 2012). Cobble and larger substrates were only present above rkm 13.4 in the Little River (Raabe 2012). In addition, upstream reaches may provide an optimal combination of food availability and predation risk for American Shad fry and juveniles (Limburg 1996). It is possible American Shad spawn in suboptimal habitat when movement is inhibited or move during freshets when conditions at their current location are no longer ideal for spawning. For example, during certain low flow periods in the Little River we captured few American Shad at the weir but did observe individuals milling downstream from the weir during the day and spawning splashes in the evening and night over fine gravel and sand areas. When flows subsequently increased weir captures increased, and we did not observe American Shad milling (possibly due to turbid water) or engaging in spawning splashes. Although our sample size was low, individuals that initiated downstream movement typically moved rapidly downstream, especially during increased flows that might have aided swimming. Our data and observations appear to contrast with Maltais et al. (2010) who stated American Shad spawning events progressed in a downstream manner because juveniles in downstream reaches hatched later in the spawning season. It is possible that later-arriving individuals may not migrate as far upstream due to no or fewer freshet events or more rapid depletion of energy reserves at higher water temperatures (Leggett 1972).

\section{Weight Loss}

Females lost more weight and a higher proportion of their initial weight compared with males. Proportional weight loss for recaptured individuals was higher for females (mean = 0.24 ) than for males (mean $=0.12$ ). For both sexes proportional weight loss was positively related to water temperature (cumulative thermal days) and the correlated duration upstream (days), and to a lesser extent minimum distance traveled, all likely due to increased metabolic rates (Leggett 1972). Estimated proportional weight loss for nonrecaptured individuals did not account for these factors but displayed similar trends as the estimated proportional weight loss for females $(0.38$ $0.48)$ was higher than it was for males $(0.09-0.26)$. Both sets of estimates are lower than in previous studies using a similar method for nonrecaptured individuals, in particular for males. Leggett (1972) estimated a mean total proportional weight loss of $0.48-0.55$ for males and 0.53 for females (estimated $40-100$ $d$ in the river) while Chittenden (1976) estimated the loss at 0.45 for males and 0.57 for females (estimated $>60 \mathrm{~d}$ in the river). Proportional weight loss likely continues to increase for American Shad that emigrate from the Little River and travel 212 rkm through the Neuse River to reach Pamlico Sound. Leggett (1969) determined full ovaries weighed a proportional average of 0.13 of female total weight while Chittenden (1976) found proportional averages of 0.14 for ovaries and 0.07 for testes. Therefore, somatic weight loss appears relatively minimal for males but more considerable for females in the Little River. Visually, emigrating males in the Little River often appeared relatively healthy while some emigrating females were emaciated, lethargic, and barely swimming or died during handling. Other studies have also found deteriorated conditions of American Shad following substantial weight loss (Walburg 1960; Leggett 1972; Chittenden 1976). Interestingly, size (especially weight) decreased in each month (March-May) for both sexes and in both directions. This may indicate larger individuals both immigrate and emigrate earlier in the season. However, laterarriving immigrants may have experienced increased energy expenditures during warmer water temperatures (Leggett 1972) or could have spawned prior to capture (e.g., in Neuse River). 


\section{Survival}

American Shad spawning mortality appears to be substantial in the Little River, consistent with the previous characterization of Neuse River populations as primarily semelparous (Leggett and Carscadden 1978). Based on our observations, angling for American Shad mostly occurred downstream from the fish weir (i.e., not in our study area), so we assumed fishing mortality was minimal. Apparent survival ranged from a low of 0.084 in 2010 to 0.238 in 2007 using only weir data; the 2007 estimate was for survival above rkm 56.4 (weir location) and individuals may not have migrated past the downstream weir location (rkm 3.7) used in other years. Survival rates incorporating antenna data in 2009 and 2010 were comparable with weir-only estimates. No previous studies have estimated within-river seasonal survival. However, in Neuse River assessments using catch curves, annual survival ranged from 0.07 to 1.00 for males and from 0.09 to 0.86 for females when using estimated age compared with $0.01-0.32$ for males and 0.02-0.42 for females when using repeat spawn marks on scales (ASMFC 2007). These estimates were highly variable and survival may differ between the main-stem Neuse River and tributary Little River and, more generally, estimates made using scales can be inaccurate and imprecise for American Shad (McBride et al. 2005). Nevertheless, seasonal spawning mortality may be the main component in annual mortality for North Carolina populations.

Factors influencing American Shad survival were not apparent in the Little River, but survival may have been influenced by flow conditions. Overall, more females were captured emigrating, but tagged individuals depicted a similar survival rate between sexes. Individuals that immigrated during weeks of higher flow (or if flow increased shortly after entry) tended to have higher survival rates, although statistical tests were unreliable. Seasonal survival estimates were slightly higher in 2008 and 2009 when large emigration events occurred in late April to early May during freshets. It is possible that increased flows aid downstream movement of physically exhausted American Shad (Jonsson 1991), and in turn their survival to emigration. In contrast, no large emigration event occurred in 2010, the year with the lowest estimated survival and no freshets from mid-April to mid-May. Throughout the river, we observed a few dead American Shad on sandbars, rock shoals, tree snags, and along the river bottom. Individuals may have succumbed to spawning mortality during low-flow periods (e.g., mid-April to mid-May in 2010) when energetically exhausted individuals were delayed at anthropogenic (e.g., notched dam) and natural migratory impediments (e.g., rock ledges, tree snags) as water temperatures rose. During low-flow periods, shallow and clear water, combined with narrower channels and migratory impediments (e.g., Goldsboro notched dam), may increase vulnerability to predation. We observed predation and predatory attempts on American Shad by Flathead Catfish Pylodictis olivaris, common snapping turtles Chelydra serpentina, and great blue herons Ardea herodias. Walburg (1960) noted white pelicans Pelecanus erythrorhynchos consumed weak and dying American Shad in the St. Johns River, Florida. While we cannot determine the extent of natural mortality due to predation, these observations highlight the importance of American Shad as contributors to marine-derived nutrients into freshwater systems (Garman and Macko 1998).

American Shad that move farther upstream may access higher quality spawning and nursery habitat at the expense of energy consumption and more emigration obstacles. The potential trade-off between higher reproductive success and decreased iteroparity has not been thoroughly examined and may vary geographically. In the Little River, we did not observe any direct relationships between survival and distance traveled upstream. Spawning survival was low overall, and this potentially limited our ability to detect influential factors. Leggett et al. (2004) suggested increased American Shad migrations following fish passage and dam removal efforts leads to higher spawning mortality, lower iteroparity, and reduced egg production but did not factor in habitat quality. Castro-Santos and Letcher (2010) developed a Connecticut River simulation model that suggested delays at dams, especially in the downstream direction, had a stronger influence on successful American Shad emigration to the ocean than did the distance traveled. Similarly, Harris and Hightower (2011) detected transported tagged American Shad remaining in Roanoke River reservoirs in North Carolina and Virginia, often just upstream from a dam, late in the spawning season and ultimately dying. Improved fish passage structures and dam removals can increase upstream and downstream passage rates and efficiency, potentially leading to lower spawning mortality, while still providing access to different habitat. Overall, survival to emigration likely varies due to a wide variety of dynamic factors including flows, water temperatures, predators, spawning habitat locations, and passage efficiency. Further estimates of within-season spawning survival can provide important information on possible factors across their geographical range.

Based on actual recaptures and estimated numbers, an apparent survival threshold of 0.5 proportional weight loss was necessary for females and 0.3 for males to emigrate from the Little River. A female with a proportional weight loss of 0.64 migrated downstream to the weir but was extremely gaunt and found dead on the weir panels. Changes in American Shad tissue weight were found to be a reliable index for the extent of energy used during migrations (Glebe and Leggett 1981); our estimates included gonadal and somatic weight loss. Glebe and Leggett (1981) determined that to reach spawning grounds, American Shad in the St. Johns River, Florida, expended 70 $80 \%$ of their total energy reserves (entirely semelparous population). In comparison, in the York River, Virginia, individuals expended approximately $30 \%$ of their energy reserves $(25 \%$ iteroparous population), and 40-60\% individual energy expenditure occurred in the Connecticut River (35\% iteroparous population; Glebe and Leggett 1981). Migration distance and speed, along with river gradient were the primary factors in energy 
expenditures (Glebe and Leggett 1981). In the Connecticut River, Leonard and McCormick (1999) found total energy depletion for American Shad ranged from 35\% to 61\% during their migration of $228 \mathrm{rkm}$ to their spawning grounds $(\sim 25 \mathrm{~kJ} / \mathrm{km}$ per fish), with differences between sexes, sizes, and years. Those authors stated an iteroparity threshold may occur in the range of 35-40\% of energy expenditure (Leonard and McCormick 1999). American Shad emigrating from the Little River must migrate an additional $212 \mathrm{rkm}$ through the Neuse River, suggesting that total spawning survival to the ocean may be even lower than our estimates.

Annual iteroparity rates were low in the Little River. American Shad are known to return to rivers of previous spawning (Melvin et al. 1986), but we documented the first known tagged individuals to return to a North Carolina river in a subsequent year. However, despite large emigration events in 2008 and 2009 when many American Shad were tagged, a very limited number returned in 2009 and $2010(<1 \%)$. The low iteroparity rate may be due to individuals spawning in a different river (e.g., Neuse River), additional energy expenditure and predation to reach Pamlico Sound, natural and fishing mortality in the ocean, and handling and tagging issues. Based on scale marks, which can be unreliable (McBride et al. 2005), Walburg (1957) determined that repeat spawners comprised less than $3 \%$ of the 1953 American Shad run in the Neuse River, and between $0 \%$ and $23 \%$ of the total annual male catch and $0-41 \%$ of the total annual female catch in the Neuse River comprised the commercial fishery from 1977 to 2005 (ASMFC 2007).

\section{Abundance}

Increasing population size is the primary goal of restoration efforts. However, estimating American Shad population size has proven to be a challenge, including the recapture of individuals (Bailey et al. 2004). Therefore, relative abundance metrics and fish passage numbers are more commonly used to assess abundance, and relatively little is known about American Shad population sizes in tributaries. Our initial goal to conduct a census of the Little River population by using a fish weir proved unfeasible due to flooding and weir failures. The number of American Shad sampled at the weir provided a minimum estimate of the population size from 2007 through 2010. Our population estimates attempted to account for unsampled individuals and ranged from 3,512 to 10,155 , displaying an increasing trend from 2007 to 2009, but then decreasing in 2010. The low estimate in 2010 may be a real trend, a result of the sampling and estimation method (very sensitive to nonrecapture emigrants), or due to natural variability that is common in many fish populations. In 2008 and 2009, estimated population sizes exceeded the 49-shad/ha conservative guideline for a healthy American Shad population (Savoy and Crecco 1994). However, all estimates were still at least $50 \%$ below the guideline of $124 \mathrm{shad} / \mathrm{ha}$ (St. Pierre 1979). It is possible the Little River American Shad population may not increase substantially after dams are removed due to other limiting factors (e.g., degraded spawning habitat, poor juvenile habitat, predation, ocean harvest). However, it is also possible that large-river guidelines estimated for northern rivers do not apply to tributaries or southern rivers or that sufficient time has not passed for the population to rebuild (Hasselman and Limburg 2012). American Shad first mature into spawning adults between ages 3 and 6 (Walburg and Nichols 1967). Dam removals commenced in 1998, with the farthest upstream habitat unavailable until Lowell Mill Dam was removed in the winter of 2005. Therefore, individuals benefiting from restored access to upstream habitat (e.g., potentially higher egg hatching rates or increased survival and growth rates of young) in 2006 would first return, at the earliest, as mature adults in 2009. As such, a positive population response to the dam removals may not yet be apparent.

\section{Conclusions}

Although American Shad have been studied for over a century (e.g., Stevenson 1899), the present research provided new information on spawning behavior and migrations relative to environmental conditions in a river with multiple dam removals and is the first to estimate spawning season survival rates and determine individual weight loss. Outside of high-flow conditions, the fish weir was effective at capturing American Shad while PIT technology allowed thousands of individuals to be tagged and monitored, including repeat spawners. During freshets, American Shad tended to migrate into upstream reaches exhibiting higher habitat complexity that may be optimal spawning and nursery habitat. Future studies evaluating survival of eggs (rather than adult presence and egg deposition) and survival and growth of young would greatly aid habitat identification, protection, and restoration efforts. Annual flow patterns may factor into use of restored habitat, reproductive output, and adult survival and could potentially be incorporated into flow regimes of regulated rivers. In the Little River, American Shad weight loss was considerable, with water temperature and duration in the river appearing to be the driving factors. Weight loss likely factors into American Shad survival, so efforts to decrease migratory impediments and delays at anthropogenic and natural obstructions would be beneficial. The Little River American Shad population appears to be healthy as two annual estimates exceeded the conservative guideline. A follow-up study, after multiple generations have accessed restored habitat, would further examine the success of dam removals for American Shad restoration.

\section{ACKNOWLEDGMENTS}

The U.S. Fish and Wildlife Service provided funding for field research. The city of Goldsboro and Cherry Hospital provided access to field sites. We thank everyone that assisted with field research, in particular Dana Sackett, Will Smith, John Bain, Donald Danesi, and Meredith Raabe. Julianne Harris, Derek Aday, Kenneth Pollock, George Hess, and Chris Caudill helped improve previous versions of this manuscript. Any use of trade, firm, or product names is for descriptive purposes only and does not imply endorsement by the U.S. Government. This study was 
performed under the auspices of North Carolina State University Institutional Animal Care and Use Committee permit 10-007-O.

\section{REFERENCES}

ASMFC (Atlantic States Marine Fisheries Commission). 2007. American Shad stock assessment. ASMFC, Stock Assessment Report 07-01, Washington, D.C.

Bailey, M. M., J. J. Isely, and W. C. Bridges Jr. 2004. Movement and population size of American Shad near a low-head lock and dam. Transactions of the American Fisheries Society 133:300-308.

Beasley, C. A., and J. E. Hightower. 2000. Effects of a low-head dam on the distribution and characteristics of spawning habitat used by Striped Bass and American Shad. Transactions of the American Fisheries Society 129:13161330.

Burdick, S. M., and J. E. Hightower. 2006. Distribution of spawning activity by anadromous fishes in an Atlantic slope drainage after removal of a low-head dam. Transactions of the American Fisheries Society 135:1290-1300.

Castro-Santos, T., A. Haro, and S. Walk. 1996. A passive integrated transponder (PIT) tag system for monitoring fishways. Fisheries Research 28:253-261.

Castro-Santos, T., and B. H. Letcher. 2010. Modeling migratory energetics of Connecticut River American Shad (Alosa sapidissima): implications for the conservation of an iteroparous anadromous fish. Canadian Journal of Fisheries and Aquatic Sciences 67:806-830.

Chittenden, M. E. Jr. 1975. Dynamics of American Shad, Alosa sapidissima, runs in the Delaware River. U.S. National Marine Fisheries Service Fishery Bulletin 73:487-494.

Chittenden, M. E. Jr. 1976. Weight loss, mortality, feeding, and duration of residence of adult American Shad, Alosa sapidissima, in fresh water. U.S. National Marine Fisheries Service Fishery Bulletin 74:151-157.

Collier, R. S., and M. C. Odom. 1989. Obstructions to anadromous fish migration. U.S. Fish and Wildlife Service, Report to North Carolina Department of Natural Resources and Community Development, Project 88-12, Raleigh, North Carolina.

Cooke, D. W., and S. D. Leach. 2003. Beneficial effects of increased river flow of upstream fish passage on anadromous alosine stocks. Pages 331-338 in K. E. Limburg and J. R. Waldman, editors. Biodiversity, status, and conservation of the world's shads. American Fisheries Society, Symposium 35, Bethesda, Maryland.

ESRI (Environmental Systems Resource Institute). 2010. ArcGIS 10.0. ESRI, Redlands, California.

Garman, G. C., and S. A. Macko. 1998. Contribution of marine-derived organic matter to an Atlantic coast, freshwater, tidal stream by anadromous clupeid fishes. Journal of the North American Benthological Society 17:277-285.

Glebe, B. D., and W. C. Leggett. 1981. Latitudinal differences in energy allocation and use during the freshwater migrations of American Shad (Alosa sapidissima) and their life history consequences. Canadian Journal of Fisheries and Aquatic Sciences 38:806-820.

Gries, G., and B. H. Letcher. 2002. Tag retention and survival of age-0 Atlantic Salmon following surgical implantation with passive integrated transponder tags. North American Journal of Fisheries Management 22:219-222.

Harris, J. E., and J. E. Hightower. 2011. Movement patterns of American Shad transported upstream of dams on the Roanoke River, North Carolina and Virginia. North American Journal of Fisheries Management 31:240-256.

Hasselman, D. J., and K. E. Limburg. 2012. Alosine restoration in the 21st century: challenging the status quo. Marine and Coastal Fisheries: Dynamics, Management, and Ecosystem Science [online serial] 4:174-187.

Hendricks, M. L. 2003. Culture and transplant of alosines in North America. Pages 303-312 in K. E. Limburg and J. R. Waldman, editors. Biodiversity, status, and conservation of the world's shads. American Fisheries Society, Symposium 35, Bethesda, Maryland.

Hewitt, D. A., E. C. Janney, B. S. Hayes, and R. S. Shively. 2010. Improving inferences from fisheries capture-recapture studies through remote detection of PIT tags. Fisheries 35:217-231.
Hightower, J. E., J. E. Harris, J. K. Raabe, P. Brownell, and C. A. Drew. 2012. A Bayesian spawning habitat suitability model for American Shad in southeastern United States rivers. Journal of Fish and Wildlife Management 3:184-198.

Hightower, J. E., A. M. Wicker, and K. M. Endres. 1996. Historical trends in abundance of American Shad and river herring in Albemarle Sound, North Carolina. North American Journal of Fisheries Management 16:257271.

Jonsson, N. 1991. Influence of water flow, water temperature and light on fish migration in rivers. Nordic Journal of Freshwater Research 66:20-35.

Jowett, I. G., J. Richardson, and M. L. Bonnet. 2005. Relationship between flow regime and fish abundances in a gravel-bed river, New Zealand. Journal of Fish Biology 66:1419-1436.

Kéry, M., and M. Schaub. 2012. Bayesian population analysis using WinBUGS: a hierarchical perspective. Elsevier, Waltham, Massachusetts.

Leggett, W. C. 1969. Studies on the reproductive biology of the American Shad (Alosa sapidissima, Wilson). A comparison of four rivers of the Atlantic seaboard. Doctoral dissertation. McGill University, Montreal.

Leggett, W. C. 1972. Weight loss in American Shad (Alosa sapidissima, Wilson) during the freshwater migration. Transactions of the American Fisheries Society 101:549-552.

Leggett, W. C., and J. E. Carscadden. 1978. Latitudinal variation in reproductive characteristics of American Shad (Alosa sapidissima): evidence for population specific life history strategies in fish. Journal of the Fisheries Research Board of Canada 35:1469-1477.

Leggett, W. C., T. F. Savoy, and C. A. Tomichek. 2004. The impact of enhancement initiatives on the structure and dynamics of the Connecticut River population of American Shad. Pages 391-405 in P. M. Jacobson, D. A. Dixon, W. C. Leggett, B. C. Marcy Jr., and R. R. Massengill, editors. The Connecticut River ecology study (1965-1973) revisted: ecology of the lower Connecticut River 1973-2003. American Fisheries Society, Monograph 9, Bethesda, Maryland.

Leggett, W. C., and R. R. Whitney. 1972. Water temperature and migrations of American Shad. U.S. National Marine Fisheries Service Fishery Bulletin 70:659-670.

Leonard, J. B. K., and S. D. McCormick. 1999. Effects of migration distance on whole-body and tissue-specific energy use in American Shad (Alosa sapidissima). Canadian Journal of Fisheries and Aquatic Sciences 56:1159-1171.

Limburg, K. E. 1996. Modelling the ecological constraints on growth and movement of juvenile American Shad (Alosa sapidissima) in the Hudson River estuary. Estuaries and Coast 19:794-813.

Limburg, K. E., K. A. Hattala, and A. Kahnle. 2003. American Shad in its native range. Pages 125-140 in K. E. Limburg and J. R. Waldman, editors. Biodiversity, status, and conservation of the world's shads. American Fisheries Society, Symposium 35, Bethesda, Maryland.

Limburg, K. E., and J. R. Waldman. 2009. Dramatic declines in North Atlantic diadromous fishes. BioScience 59:955-965.

Maltais, E., G. Daigle, G. Colbeck, and J. J. Dodson. 2010. Spawning dynamics of American Shad (Alosa sapidissima) in the St. Lawrence River, CanadaUSA. Ecology of Freshwater Fish 19:586-594.

McBride, R. S., M. L. Hendricks, and J. E. Olney. 2005. Testing the validity of Cating's (1953) method for age determination of American Shad using scales. Fisheries 30(10):10-18.

Melvin, G. D., M. J. Dadswell, and J. D. Martin. 1986. Fidelity of American Shad, Alosa sapidissima (Clupeidae), to its river of previous spawning. Canadian Journal of Fisheries and Aquatic Sciences 43:640-646.

Olney, J. E., and J. M. Hoenig. 2001. Managing a fishery under moratorium: assessment opportunities for Virginia's stocks of American Shad. Fisheries 26(2):6-12.

Olney, J. E., D. A. Hopler Jr., T. P. Gunter Jr., K. L. Maki, and J. M. Hoenig. 2003. Signs of recovery of American Shad in the James River, Virginia. Pages 323-329 in K. E. Limburg and J. R. Waldman, editors. Biodiversity, status, and conservation of the world's shads. American Fisheries Society, Symposium 35, Bethesda, Maryland. 
Olney, J. E., R. J. Latour, B. E. Watkins, and D. G. Clarke. 2006. Migratory behavior of American Shad in the York River, Virginia, with implications for estimating in-river exploitation from tag recovery data. Transactions of the American Fisheries Society 135:889-896.

Plummer, M. 2003. JAGS: a program for analysis of Bayesian graphical models using Gibbs sampling. In K. Hornik, F. Leisch, and A. Zeileis, editors. Proceedings of the 3rd international workshop on distributed statistical computing. Austrian Association for Statistical Computing and R Foundation for Statistical Computing, Vienna.

Plummer, M. 2012. JAGS version 3.2 user manual. Available: http://mcmcjags.sourceforge.net/. (October 2013).

Prentice, E. F., T. A. Flagg, and C. S. McCutcheon. 1990. Feasibility of using implantable passive integrated transponder (PIT) tags in salmonids. Pages 317-322 in N. C. Parker, A. E. Giorgi, R. C. Heidinger, D. B. Jester Jr., E. D. Prince, and G. A. Winans, editors. Fish-marking techniques. American Fisheries Society, Symposium 7, Bethesda, Maryland.

R Development Core Team. 2012. R: a language and environment for statistical computing. R Foundation for Statistical Computing, Vienna. Available: http://www.r-project.org. (October 2013).

Raabe, J. K. 2012. Factors influencing distribution and survival of migratory fishes following multiple low-head dam removals on a North Carolina river. Doctoral dissertation. North Carolina State University, Raleigh.

Royle, J. A. 2008. Modeling individual effects in the Cormack-Jolly-Seber model: a state-space formulation. Biometrics 64:364-370.

Savoy, T., and V. Crecco. 1994. Memorandum re: Thames River goals. Connecticut Department of Environmental Protection, Hartford.
St. Pierre, R. A. 2003. A case history: American Shad restoration on the Susquehanna River. Pages 315-321 in K. E. Limburg and J. R. Waldman, editors. Biodiversity, status, and conservation of the world's shads. American Fisheries Society, Symposium 35, Bethesda, Maryland.

St. Pierre, R. S. 1979. Historical review of American Shad and river herring fisheries of the Susquehanna River. U.S. Fish and Wildlife Service, Special Report to the Susquehanna River Basin Committee, Harrisburg, Pennsylvania.

Stevenson, C. H. 1899. The shad fisheries of the Atlantic coast of the United States. Pages 101-269 in Report of the Commissioner for the year ending June 30, 1898, part 24. U.S. Commission of Fish and Fisheries, Washington, D.C.

Stewart, R. 2002. Resistance board weir panel construction manual. Alaska Department of Fish and Game, Regional Information Report 3A02-21, Anchorage.

Walburg, C. H. 1957. Neuse River shad investigation. U.S. Fish and Wildlife Service Special Scientific Report Fisheries 206.

Walburg, C. H. 1960. Abundance and life history of shad, St. Johns River, Florida. U.S. Fish and Wildlife Service Fishery Bulletin 60:487-501.

Walburg, C. H., and P. R. Nichols. 1967. Biology and management of the American Shad and status of the fisheries, Atlantic coast of the United States, 1960. U.S. Fish and Wildlife Service Special Scientific Report Fisheries 550.

Weaver, L. A., M. T. Fisher, B. T. Bosher, M. L. Claud, and L. J. Koth. 2003. Boshers Dam vertical slot fishway: a useful tool to evaluate American Shad recovery efforts in the upper James River. Pages 339-347 in K. E. Limburg and J. R. Waldman, editors. Biodiversity, status, and conservation of the world's shads. American Fisheries Society, Symposium 35, Bethesda, Maryland. 